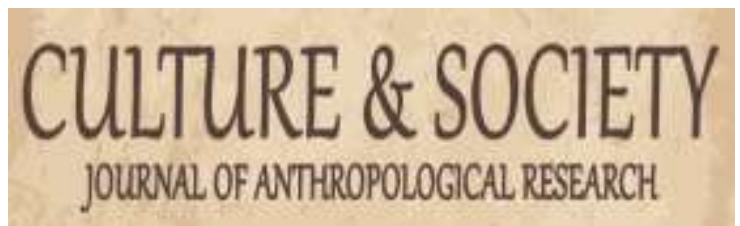

Culture \& Society: Journal of Anthropological Research

VOL. 3 NO. 1 SEPTEMBER 2021

http://culture.ppj.unp.ac.id

Email: culture@ppj.unp.ac.id

ISSN: 2686-343X (E-ISSN) 2686-3421 (P-ISSN)

DOI: https://doi.org/10.24036/csjar.v3i1.86

\title{
Pengetahuan Suami Mengenai Suami Siaga
}

\author{
Rahmi Izzati ${ }^{1}$, Erda Fitriani ${ }^{2}$ \\ ${ }^{1,2}$ Universitas Negeri Padang \\ Email: rahmiizzati125@gmail.com, fitriani_cim@fis.unp.ac.id.
}

\begin{abstract}
Abstrak
Artikel ini didasari oleh tingginya angka kematian ibu pada saat melahirkan, dan disini dituntut adanya pengetahuan suami terhadap Suami Siaga di Nagari Pakan Rabaa, Kecamatan Koto Parik Gadang Diateh, Kabupaten Solok Selatan. Penelitian ini bertujuan untuk mendeskripsikan dan menjelaskan pengetahuan suami mengenai Suami Siaga. Penelitian ini dilakukan dengan pendekatan kualitatif dengan jenis penelitian studi Etnosains. Teknik pemilihan informan dilakukan dengan cara purposive sampling (sampel bertujuan) dengan jumlah informan sebanyak 29 orang. Dalam pengumpulan data dilakukan dengan cara observasi, wawancara dan studi dokumentasi dengan teknik analisis data dari Spradley. Data dianalisis dengan teori Etnosains yang dikemukan oleh James Spradley. Berdasarkan hasil penelitian diperoleh bahwa pengetahuan suami tentang Suami Siaga diperoleh dari informasi keluarga, teman, dan internet. Pengetahuan mengenai suami siaga terdiri atas: 1). pengetahuan suami mengenai penyelamatan ibu hamil melalui pertolongan pertama, 2). Pengetahuan suami mengenai tanda-tanda akan melahirkan ditandai oleh pecah air ketubanm 3). Pengetahuan suami mengenai bahaya melahirkan terlalu tua dan terlalu muda, 4). Pengetahuan suami dalam perawatan kehamilan, yang meliputi gizi ibu hamil dan pemeriksaan kehamilan, 5). Pengetahuan suami mengenai tanda-tanda bahaya dari kehamilan.
\end{abstract}

Kata Kunci: Ibu hamil, Pengetahuan, Suami siaga

\begin{abstract}
This article is base on the high maternal mortality rate during childbirth, and here it is demanded that the husband's knowledge of the Alert Husband be in Nagari Pakan Rabaa, Koto Parik Gadang Diateh District, South Solok Regency. This study aims to describe and explain the knowledge of the Alert Husband. This research was conducted with a qualitative approach with the type of research study Ethnoscience. The informant selection technique was carried out by purposive sampling (purposed sample) with a total of 29 informants. Data collection was done by means of observation, interviews and documentation studies with data analysis techniques from Spradley. The data were analyzed by using the theory of ethnoscience proposed by James Spradley. Based on the results of the study, it was found that the husband's knowledge about the Alert Husband was obtained from family information, friends, and the internet. Knowledge of the standby husband consists of: 1). husband's knowledge about saving pregnant women through first aid, 2). Husband's knowledge of the signs of giving birth is marked by the rupture of the amniotic fluid, 3). Husband's knowledge about the dangers of giving birth is too old and too young, 4). Husband's knowledge in pregnancy care, which includes nutrition for pregnant women and prenatal care, 5). Husband's knowledge about the danger signs of pregnancy.
\end{abstract}

Kata kunci: Alert husband, Knowledge, Pregnant woman

\begin{tabular}{l|l|l} 
Received: August 3, 2021 & Revised: September 26, 2021 & Published: September 29, 2021
\end{tabular}

Culture \& Society: Journal of Anthropological Research Vol. 3, No. 1, Th. 2021 


\section{Pendahuluan}

Dalam masalah kehamilan tentu seorang suami harus siap siaga dalam menjaga kehamilan seorang istri. Melahirkan bayi yang normal dan sehat merupakan harapan bagi suami istri. Menjaga kehamilan berarti harus menjaga makanan yang sehat dan banyak memakan buahbuahan, serta memeriksakan kandungan ke dokter. Upaya pemeliharaan kesehatan kehamilan tidak semata-mata ditujukan kepada aspek fisik saja, tetapi aspek Psikologis juga perlu diperhatikan agar kehamilan dan persalinan berjalan lancar (Yudiharto, 2016). Kehamilan dan persalinan adalah suatu krisis maturitas yang dapat menimbulkan kecemasan atau bahkan stres, tetapi berharga karena wanita menyiapkan diri untuk memberi perawatan dan mengemban tanggung jawab yang lebih besar (Yudiharto,2016). Upaya pelayanan kesehatan bagi ibu hamil adalah melalui pelayanan dan pemeliharaan ibu hamil, misalnya dengan Program Gerakan Sayang Ibu (GSI) yang bertujuan untuk meningkatkan kualitas hidup perempuan sebagai sumber daya manusia, khususnya pada saat persalinan yang sehat (Depkes RI, 2007).

Menjaga dan merawat bayi bukan suatu yang mudah, karena masih ada ibu hamil yang mengabaikan kesehatannya sehingga dapat melahirkan bayi yang tidak normal (Raudatussalamah \& Pevi Primasnia, 2012). Masyarakat masih ada yang beranggapan bahwa hamil adalah hal yang biasa dan tidak perlu mendapatkan perhatian yang berlebihan. Sikap dan perilaku ini bukan hanya datang dari pihak wanita, melainkan pihak laki-laki atau suami, dan keluarga yang lebih luas (Kartono, 1996). Pada saat kehamilan suami ikut berpatisipasi dengan cara ikut menemani istri ke dokter, merawat kehamilan istri, dan menemani istri saat melahirkan bayi, dalam keadaan ini suami adalah penting bagi istri. Suami juga harus menemani istri konsultasi sehingga suami juga dapat belajar mengenai gejala dan tanda-tanda komplikasi dan gizi yang baik serta istirahat yang cukup selama masa kehamilan (Lucianawaty, 2004).

Angka kematian ibu (AKI) adalah jumlah kematian selama kehamilan atau dalam periode 42 hari setelah berakhirnya kehamilan, yang diakibatkan karena masalah yang diperberat oleh kehamilan atau penanganannya, tetapi bukan disebabkan oleh kecelakaan atau cedera (WHO, 2014). Berdasarkan data laporan kematian ibu di Dinas Kesehatan Provinsi Sumatera Barat pada tahun 2017 sebanyak 107 kasus. Rincian kematian ibu terdiri atas kematian ibu hamil sebanyak 30 orang, kematian ibu bersalin sebanyak 25 orang, dan kematian ibu nifas sebanyak 52 orang. Berdasarkan laporan yang diperoleh dari Dinas Kesehatan Kabupaten Solok Selatan Pada tahun 2015 terjadi sebanyak 19 kasus kematian ibu. Sedangkan menurut Bidan Desa Ibu Maya (40 Tahun), pada tahun 2020 angka kematian ibu di Pakan Rabaa sebanyak 4 orang, dan pada tahun 2021 pada bulan Maret 1 orang, dan kehamilan resiko tinggi merupakan salah satu penyebab tingginya angka kematian ibu.

Program Suami Siaga dibentuk dari tahun 2000, dengan tujuan Program ini bisa meningkatkan pengetahuan, partisipatif serta keterlibatan suami tentang pelayanan ibu dan bayi yang baru lahir (Depkes RI, 2001). Suami Siaga adalah kewaspaan suami terhadap istri untuk menjaga kesehatan serta keselamatan istri yang sedang hamil sampai pada saat persalinannya tiba. Pengetahuan suami pada Program Suami Siaga ini sangat dibutuhkan oleh ibu hamil, sehingga bisa menurunkan angka kematian pada ibu. Untuk menjadi suami yang benar siaga, harus dibekali dengan pengetahuan tentang beberapa hal yaitu, a). Upaya menyelamatkan ibu hamil; b). Mengenal tanda bahaya dan siap mengambil keputusan; c). Tidak terlambat mencapai fasilitas kesehatan; d). Tidak terlalu muda untuk hamil; e). Tidak terlalu tua untuk hamil; f). Tidak terlalu banyak anak; g). Tidak terlalu dekat usia kehamilan dan mengatasi masalah kehamilan secara cepat.

Suami Siaga jika dijalankan dengan baik, maka dapat diharapkan keterlambatan yang kerap menjadi penyebab kematian ibu melahirkan tidak akan terjadi. Keterlambatan yang dimaksud mencakup terlambat mengetahui kelainan kehamilan dan persalinan, terlambat memutuskan untuk segera ke fasilitas pelayanan kesehatan, terlambat menerima perawatan yang tepat ( Yulifah, 2014). Dalam konsep Suami Siaga, seorang suami dengan istri yang sedang hamil diharapkan siap

Culture \& Society: Journal of Anthropological Research Vol. 3, No. 1, Th. 2021 
mewaspadai setiap risiko kehamilan yang muncul, menjaga agar istri tidak melakukan hal-hal yang mengganggu kesehatan dan kehamilannya, serta segera mengantar ke rujukan terdekat bila ada tanda-tanda komplikasi kehamilan.

Pengetahuan suami mengenai Suami Siaga sangat diperlukan, karena menyangkut kesehatan ibu dan bayi, diasumsikan bahwa pengetahuan suami mengenai Suami Siaga masih sangat kurang dan masih jauh dari yang diharapkan. Untuk itu bisa diharapkan dapat berjalan dengan baik, agar tidak meningkatnya angka kematian ibu. Berdasarkan penelitian yang dilakukan Karlina (2018) tingkat pengetahuan suami tentang pengertian Suami Siaga adalah sebesar 67,3\% tentang peran dan keterlibatan suami dalam masa kehamilan adalah cukup besar 49,1 (Karlina L, 2018). Asrifah (2018) menjelaskan tentang hubungan pengetahuan usia ibu hamil dengan kehamilan resiko tinggi (Asrifah, 2018).

Selanjutnya penelitian Nasution (2013) diperoleh informasi bahwa suami mereka masih kurang peduli dengan masalah hiperemesis gravidarum yang dihadapinya, bahkan suami tidak ikut mendampingi istri memeriksakan kandungan ke puskesmas ( Nasution 2013). Rima Melati menemukan adanya hubungan dukungan sosial suami dengan motivasi dalam menjaga kesehatan selama kehamilan (Melati, 2012). Dari penelitian yang sudah ada menunjukkan bahwa penelitian mengenai pengetahuan suami mengenai Suami Siaga belum dikaji oleh peneliti lain. Penelitian ini mengkaji pengetahuan suami mengenai Suami Siaga, yang selanjutnya menjadi kebaruan dalam penelitian ini. Penelitian dilakukan di Nagari Pakan Rabaa Kecamatan Koto Parik Gadang Diateh Kabupaten Solok Selatan

\section{Metode Penelitian}

Penelitian ini dilakukan dengan pendekatan kualitatif. Di dalam metode ini penelitian menghasilkan data deskriptif yang secara tertulis atau lisan dari orang-orang dan perilaku yang dapat dialami serta dapat memahami masalah yang ada di dalam permasalahan sosial (Bogdan dan Taylor, 2014). Penelitian kualitatif dipilih karena mampu menjelaskan pengetahuan suami mengenai Suami Siaga di masyarakat Nagari Pakan Rabaa, Kecamatan Koto Parik Gadang Diateh Kabupaten Solok Selatan. Pendekatan yang ada dalam penelitian kualitatif bisa mengamati orang yang ada di lingkungan hidup, serta bisa berinteraksi dengan mereka dan berusaha memahami bahasa dan tafsiran mereka terhadap dunianya (Muhammad, 2013). Jenis penelitian yang dipakai adalah jenis studi Etnosain dimana peneliti berusaha memahami sistem pengetahuan yang khas dari suatu masyarakat, dan berbeda dengan sistem pengetahuan masyarakat yang lain, bahwa kesiagaan suami terhadap kehamilan istri sangat dibutuhkan. Peneliti memberikan tafsiran tentang pengetahuan suami terhadap kehamilan istri, sehingga bisa mengurangi akibat dari angka kematian ibu, karena suami adalah tempat dalam pengambilan keputusan. Etnosains dapat dianggap sebagai system of knowledge and cognition typical of a given culture (Suastra, 2006).

Dalam studi etnosains, strategi adaptasi terhadap lingkungan bagi suatu masyarakat dipengaruhi oleh kebudayaan. Kebudayaan merupakan sistem ide dan pengetahuan yang dimiliki suatu masyarakat mempengaruhi pola tindakan mereka. Haviland menyatakan bahwa manusia beradaptasi melalui medium kebudayaan ketika mereka mengembangkan cara-cara untuk mengerjakan sesuatu sesuai dengan sumber daya yang dimiliki dan juga dalam batas-batas lingkungan tempat mereka hidup (Haviland, 1985). Dalam penelitian ini bisa memberikan eksistensi terhadap para suami pentingnya menjaga kehamilan pada sang istri sehingga bisa mengurangi akibat dari tingginya angka kematian pada ibu.

Penelitian ini dilakukan di Nagari Pakan Rabaa Kecamatan Koto Parik Gadang Diateh Kabupaten Solok Selatan. lokasi ini dipilih karena terdapat tingginya angka kematian ibu, dan disini dituntut adanya pengetahuan suami terhadap Suami Siaga sehingga bisa menurukan angka kematian ibu. Teknik pemilihan informan dengan cara purposive sampling (sampel bertujuan). Informan dalam penelitian berjumlah 29 orang diantaranya 22 orang suami yang istrinya sedang hamil, 4 orang bidan desa, 2 orang Aparat Nagari 1 orang masyarakat. Metode pengumpulan data

Culture \& Society: Journal of Anthropological Research Vol. 3, No. 1, Th. 2021 
dilakukan dengan cara wawancara, teknik pengamatan (observasi), dan studi dokumentasi. Dalam penelitian ini menggunakan triangulasi data. Analisis data dilakukan menggunakan yakni model analisis maju bertahap menurut Spradley (Spradley, 1997).

\section{Hasil dan Pembahasan}

Penelitian tentang pengetahuan suami mengenai Suami Siaga dilakukan di Nagari Pakan Rabaa Kecamatan Koto Parik Gadang Diateh Kabupaten Solok Selatan. Kabupaten Solok Selatan terletak di bagian timur Provinsi Sumatera Barat. Kabupaten ini resmi dimekarkan dari Kabupaten Solok pada tahun 2004 mencakup wilayah seluas 3.346,20 km² Nagari Pakan Rabaa merupakan satu dari 12 Nagari asal Kabupaten Solok Selatan. Penelitian ini dilakukan dengan pendekatan kualitatif. Pada tahun 2007 Wilayah Kecamatan Koto Parik Gadang Diateh terdiri dari 4 Nagari yaitu Nagari Pakan Rabaa, Nagari Pakan Rabaa Tengah, Nagari Pakan Rabaa Utara dan Nagari Pakan Rabaa Timur. Namun dalam penelitian ini penulis melakukan penelitian di Nagari Pakan Rabaa karena terdapat ibu hamil yang melahirkan dan mengalami kematian.

\section{Pengetahuan suami tentang Suami Siaga}

Suami Siaga adalah Program yang dicanangkan oleh Pemerintah sejak dari tahun 2000, Program ini diperuntukkan kepada suami yang diberlakukan untuk menjaga istrinya dalam keadaan hamil, disini tugas suami dilihat dari segi kesiapan, kesiagaan dan suami bersedia mengantarkan istri jika diperlukan, begitu pun sebaliknya di Nagari Pakan Rabaa Kecamatan Koto Parik Gadang Diateh Kabupaten Solok Selatan pengetahuan suami sangat dibutuhkan.

Dengan minimnya pengetahuan suami terhadap kehamilan istri tentu ini akan mendongkrak tingginya angka kematian ibu, pada tahun 2020 angka kematian ibu di Pakan Rabaa sebanyak 4 orang, dan pada tahun 2021 pada bulan Maret 1 orang. Dengan keadaan dan situasi seperti ini maka masyarakat terkhususnya untuk para suami harus mengetahui apa Suami Siaga itu. Di dalam pengertian Suami Siaga, seorang suami dengan istri yang sedang hamil, diharapkan bisa untuk menemani istrinya dan memberikan motivasi serta memberikan dukungan sepenuhnya, dan suami siap siaga untuk melakukan hal-hal bila terjadi tanda-tanda komplikasi pada kehamilan istrinya. Untuk mengetahui pengetahuan suami pada Suami Siaga maka ditemukan hasil dilapangan:

\section{Sumber informasi}

Sumber informasi adalah tempat dimana seseorang untuk memperoleh informasi, dimana informasi itu muncul agar yang menerima objek tersebut bisa bertambah pengetahuan dan wawasannya. Di lapangan ditemukan bahwa sumber informasi dari para suami terhadap Suami Siaga diperoleh melalui media sosial, teman, dan keluarga. Sedangkan pengetahuan yang diperoleh melalui penyuluhan tidak didapatkan oleh para suami. Seperti ditemukan di lapangan yang disampaikan oleh suami Syafriyun (29 tahun):

\footnotetext{
"Kalau pengetahuan tentang Suami Siaga ini saya belum paham, belum pernah saya mendengar tentang Progran ini, karena penyuluhan dari Pos Pelayanan Terpadu (Posyandu) tempat istri saya memeriksakan kehamilannya tidak pernah diberi penyuluhan tentang Program Suami Siaga ini, sekarang tergantung ke diri masingmasing harus berpandai-pandai untuk menjaga kehamilan istri agar tidak terjadi halhal komplikasi yang akan membahayakan istri dan calon anak saya."
}

Ketika peneliti menjelaskan tentang yang dimaksud dengan suami siaga yaitu kesiapan para suami dalam menunggu masa kelahiran istrinya, mereka mengatakan bahwa informasi mengenai kesiapan untuk menjelang kelahiran istrinya diperoleh dari teman, kerabat dan orang tua (termasuk mertua).

\section{Pengetahuan suami dalam upaya penyelamatan ibu hamil}


Penyelamatan pelayanan pada masa hamil bertujuan untuk memenuhi hak setiap ibu hamil untuk memperoleh layanan kesehatan yang berkualitas, maka disini untuk penyelamatan ibu hamil pengetahuan suami sangat dituntut dan harus diberikan.

\section{Pemberian pertolongan pertama}

Pemberian pertolongan pertama adalah pemberian pertolongan segera kepada penderita untuk memerlukan penanganan medis secara dasar. Untuk pertolongan pertama ini belum diatur secara khusus, tetapi merujuk kepada pasal 531 KUHP. Dalam pelaksanaan pertolongan pertama terdapat beberapa tujuan, diantaranya, Menyelamatkan jiwa penderita, mencegah kecacatan, memberikan rasa nyaman dan menunjang proses penyembuhan. Ini sesuai dengan pernyataan Informan bapak Zainal (39 tahun):

"Ketika istri saya hamil anak pertama, upaya saya dalam situasi yang darurat itu adalah menelpon bidan tempat istri saya memeriksakan kandungannya. Tetapi untuk hamil yang kedua ini saya sudah mengerti apa yang harus dilakukan dan upaya apa yang harus saya lakukan jika terjadi hal yang membahayakan untuk istri saya. Selama istri saya hamil dia tidak boleh bekerja, sebab itu akan membahayakan dia dan calon bayi, untuk pekerjaan rumah saya yang mengerjakan semuanya."

Pertolongan pertama yang paling dominan adalah suami, karena suami yang mengerti bagaimana keadaan istrinya, tidak terlepas dari perhatian sang suami. Untuk hal yang demikian suami tidak boleh mengabaikan keadaan istrinya. Pertolongan pertama pada saat istri hamil sangat diperlukan dan suami harus bersedia untuk melakukan yang terbaik untuk istrinya, ini sesuai dengan penjelasan yang utarakan oleh informan Yefriadi (30 tahun):

"Upaya yang saya lakukan untuk menyelamatkan istri saya ketika dia sakit adalah cepat saya bawa ke tempat bidan pada saat memeriksakan kandungannya. Kasihan saya melihat istri ketika dia merasakan sakit yang berlebihan, yang paling utama adalah istri dan anak saya sehat."

Untuk itu yang dilakukan para suami adalah pilihan yang cepat pada saat pertolongan pertama dengan segera membawa istrinya untuk menemui bidan. di Nagari Pakan Rabaa terdapat beberapa bidan desa yang kompeten terhadap ibu hamil. Dari hasil wawancara dengan informan di atas suami menjelaskan bahwasanya untuk pertolongan pertama pada istrinya di Nagari Pakan Rabaa mereka selalu memberikan yang terbaik, karena yang terpenting adalah bagaimana mereka bisa membuat istrinya merasa berkecukupan dan merasa tenang, disini terlihat bagaimana perlakuan suami kepada istri yang sedang hamil. Pola perilaku didasarkan atas pengetahuan dan pengalaman, dan proses adaptasi dengan lingkungan. Hal ini sesuai dengan teori etnosain yang mana teori ini mengungkapkan seperangkat pengetahuan yang dimiliki oleh suatu masyarakat yang secara empiris dapat dipertanggungjawabkan kebenarannya. Suami bisa memberikan pertolongan terhadap istrinya yang sedang hamil dengan melihat situasi atau pengalaman yang terjadi langsung.

\section{Pengetahuan suami tanda-tanda akan melahirkan}

\section{Air ketuban pecah}

Tanda-tanda akan melahirkan yang diketahui oleh suami adalah pecahnya air ketuban. Kebanyakan ibu hamil akan lebih dulu merasakan kontraksi sebelum air ketuban pecah, disini ada juga ibu yang mengalami pecahnya ketuban terlebih dahulu. Ketika hal ini terjadi, biasanya persalinan akan segera menyusul. Seperti yang disampaikan Informan Rusdi (30 tahun):

“...untuk tanda-tanda mau melahirkan ini, saya pernah membaca di google, terus ada juga pengalaman istri adik saya yang sudah melahirkan, itu ketuban nya pecah. Sekarang kan istri saya sudah hamil 9 bulan jadi saya harus waspada apa-apa saja 
yang dia rasakan. Saya selalu ada untuk dia karena ini tinggal menghitung hari jika seandainya terjadi kontraksi saya akan segera menghubungi bidan tempat istri saya memeriksakan kandungannya."

Suami yang bertanggung jawab terhadap kehamilan istrinya tentu sangat besar sekali bimbingan dari suami, disini suami tidak hanya dituntut untuk mencari nafkah saja, perhatian secara psikologis juga dibutuhkan pada saat istri hamil. Pernyataan yang sama juga dilontarkan oleh Fetriadi (39 tahun):

"...untuk tanda-tanda mau melahirkan mungkin saya banyak mendapatkan informasi dari teman-teman saya yang sudah menikah, karena saya menikah sudah dikatakan umur yang cukup tua, sekarang umur saya sudah 39 dan istri saya 38. Untuk tandatanda akan melahirkan yang saya tahu, mungkin istri saya akan merasakan kram pada tempat tertentu, karena pengalaman-pengalam saya membaca dari internet. Kemaren itu pas setelah selesai menikah, istri saya langsung hamil, tapi mungkin belum rezeki, karena keguguran masuk hamil 2 bulan. Tapi sekarang istri saya hamil 7 bulan, dan disini saya harus menambah pengetahuan tentang tanda-tanda akan melahirkan."

Di dalam proses tanda-tanda melahirkan ini masih banyak yang bisa dirasakan oleh ibu hamil, tetapi disini yang paling dominan adalah pecah air ketuban. Disini terlihat bagaimana dan harus melakukan apa ketika seorang istri hendak memasuki persalinan.

\title{
Pengetahuan suami terlalu tua untuk hamil dan terlalu muda
}

Kehamilan di usia tua adalah kehamilan yang terjadi pada wanita yang sudah berumur lebih dari 35 ke atas. Semua kehamilan memiliki resiko, dan resiko tersebut akan semakin meningkat pada saat kehamilan di usia tua. Sedangkan terlalu muda untuk hamil adalah di saat usia 20 tahun ke bawah. Kehamilan di bawah umur tidak kalah berisiko pada usia kehamilan tua. Secara ilmu kedokteran wanita yang hamil pada usia di bawah umur 20 tahun, organ reproduksi belum siap untuk berhubungan seks atau mengandung, sehingga terjadi kehamilan resiko tinggi yang akan mengalami tekanan darah tinggi (karena tubuhnya yang tidak kuat). Seperti yang ditemui di lapangan yang disampaikan oleh suami Bambang (36 tahun):

\begin{abstract}
"Pengetahuan saya tentang kehamilan di umur yang sudah tua dari 35 tahun ke atas itu sedikit rentan, sebenarnya saya sudah menikah 5 tahun mungkin belum rezeki sebelumnya, dan untuk berobat saya lakukan, dan alhamdulilah istri saya bisa hamil juga, dan sekarang kandungan istri saya sudah masuk 7 bulan. Apalagi hamil yang masih muda sekarang yang belum cukup umur 18 tahun sudah menikah dan hamil, itu kan sebenarnya rahim nya belum kuat untuk menerima, yang akan berdampak akan keguguran, jadi saya sarankan kalau mau menikah setidak nya cukupkan umur, setidaknya umur 20 tahun keatas.
\end{abstract}

Dengan adanya kehamilan pada wanita yang sudah melebihi umur 35 tahun ke atas resiko yang akan diterima tentu lebih besar di banding pada usia yang 25-35 tahun, ini dilihat dari fakta yang ada di dalam masyarakat yang di Nagari Pakan Rabaa yang disampaikan oleh suami Supri (28 tahun):
"Untuk yang hamil seandainya umur nya sudah tua sedikit susah karena resiko nya tinggi, disini kemaren ada tetangga umurnya sudah 43 tahun, dan melahirkan anak kareana HB rendah akhirnya ibu itu meninggal, mungkin karena faktor umur juga ada. Kalau untuk yang hamil terlalu muda ini sebenarnya juga tidak disarankan atau tidak boleh, takutnya nanti dia belum bisa bereproduksi dengan baik, belum siap rahimnya untuk menerima. Takutnya berimbas kepada diri sendiri nanti, resikonya lebih besar contohnya keguguran, karena diusia 20 tahun kebawah emosi nya masih belum stabil yang masih berubah-ubah, dan mentalnya belum siap untuk menerima." 
Di dalam permasalahan ini suami benar-benar harus dituntut pengetahuannya terhadap permasalahan terlalu tua untuk hamil dan terlalu muda untuk hamil, sebab disini jika seandainya terlalu tua untuk hamil tentu akan menyebabkan resiko terhadap istrinya, disini studi etnosains menjadi pastisipan didalam menjalani praktik kehidupan sehari-hari. Dalam domain pengetahuan disini para suami tahu hal-hal yang mengakibatkan faktor dari kehamilan terlalu tua dan terlalu muda. Para suami disini juga mengetahui faktor dari resiko tinggi kehamilan pada istri juga disebabkan dari kehamilan yang muda dan terlalu tua untuk hamil.

\section{Pengetahuan suami tentang perawatan kehamilan}

\section{Gizi pada ibu hamil}

Makanan yang dikonsumsi oleh ibu hamil yang baik adalah sayur-sayuran dan buahbuahan dan banyak mengkomsumsi makanan yang mengandung protein, dan karbohidrat. Sesuai yang ditemukan di lapangan yang dilontarkan oleh Hendri (39 tahun):

\footnotetext{
"Untuk makanan yang baik di konsumsi oleh istri saya harus saya pikirkan baik-baik, untuk makanan yang dikonsumsi oleh istri saya menyarankan banyak memakan sayur-sayuran. Istri saya juga mengkonsumsi vitamin dari bidan tempat dia memeriksakan kandunganya nama vitamin nya "gestiamin" untuk vitamin yang ini istri saya selalu konsumsi."
}

Kebutuhan gizi pada saat istri hamil tentu harus dipenuhi dengan bijak, jika kebutuhan istri tidak terpenuhi saat hamil, tentu akan beresiko terhadap kandungannya, tidak hanya kandungan tetapi juga akan beresiko terhadap kesehatan ibunya, ini sesuai dengan yang dilontarkan oleh suami Idil (30 tahun):
"Untuk istri saya yang paling utama gizi saya cukupi, pada saat memeriksakan kandungan ke bidan saya selalu menemanin istri saya, dan apa yang boleh dimakan dan yang tidak bolehuntuk dimakan, karena kesehatan calon bayi saya sangat penting."

Kebutuhan gizi istri semata-mata bukan untuk dirinya sendiri tetapi juga diperlukan untuk pertumbuhan bayi yang sedang dikandung, ibu hamil harus banyak mengkonsumsi karbohidrat ini sangat penting untuk menyuplai energi tubuh. Setelah dicerna dalam perut, karbohidrat akan diubah menjadi glukosa yang menjadi sumber utama energi tubuh. Asupan glukosa ini akan menjadi nutrisi atau zat gizi pada ibu hamil yang penting bagi janin dan mendukung proses tumbuh kembangnya di dalam kandungan. Pernyataan yang sama juga jelaskan oleh suami Devi (33 tahun):

"Gizi untuk istri saya terus saya penuhi selama masa kehamilan, karena itu termasuk salah satu perawatan ibu hamil. Kalau untuk pergi posyandu saya selalu menemani untuk kontrol ke bidan, yang saya inginkan hanya satu ketika istri saya melahirkan sehat beserta dengan calon bayi."

Untuk kebutuhan gizi ibu hamil benar-benar harus dijaga dengan baik, mulai dari makanan, vitamin, susu, serta karbohidrat yang ia konsumsi. Tidak terkecuali hal ini dilakukan supaya anak yang ada didalam kandungannya mendapatkan nutrisi yang baik.

\section{Pemeriksaan kehamilan}

Kemenkes RI merekomendasikan setiap ibu hamil untuk memeriksakan kandungan secara berkala setidaknya 4 (empat) kali. Ibu hamil memiliki standar sendiri dalam waktu kunjungan, yaitu, trimester pertama 1 kali kunjungan selama usia kehamilan 0-13 minggu, trimester kedua 1 kali kunjungan selama usia kehamilan 14-27 minggu, trimester ketiga 2 kali kunjungan selama 
usia kehamilan 28 sampai waktu kelahiran. Sebagaimana yang diungkapkan oleh suami Candra (26 tahun),
"Sekarang istri saya sedang mengandung 7 bulan, dan saya selalu menemani istri untuk menemani ke bidan, karena itu suatu kebanggaan untuk istri saya ketika saya menemaninya. Untuk pengetahuan saya tentang perawatan kehamilan ini ada senam hamil yang dilakukan oleh ibu hamil, tetapi untuk istri saya tidak pernah melakukan senam ibu hamil, tapi melakukan sekali 3 hari untuk jalan pagi, mungkin nanti ketika sudah masuk kehamilan 9 bulan di usahakan untuk selalu jalan pagi. Untuk wawasan saya yang lain mungkin pesan saya dia harus pandai-pandai untuk merawat diri."

Selaku suami tentu harus mengedepankan kepentingan istri dan merawat kesehatan istri pada saat hamil. Sudah menjadi kewajiban suami untuk menemani istri, serta mengamati perkembangan janin yang sedang dia kandung.

\title{
Pengetahuan suami tentang tanda-tanda bahaya kehamilan
}

Tanda-tanda bahaya kehamilan ialah tanda-tanda yang mengindikasikan adanya bahaya yang dapat terjadi selama kehamilan atau periode antenatal, yang menyebabkan kematian ibu (Notoatmodjo, 2017). Bahaya kehamilan perlu diberi penyuluhan kepada para suami beserta ibu hamil, penyuluhan yang diberikan bisa untuk menambah pengetahuan akan tanda-tanda bahaya kehamilan. Ini sesuai dengan yang dilontarkan oleh suami Uul (28 tahun):

\begin{abstract}
"Untuk bahaya kehamilan ini saya banyak mendapatkan informasi dari yang tua dan media sosial, contoh nya saja tetangga saya yang hamil sekitar 5 bulan, karena bekerja terlalu keras, karena suaminya yang bekerja dari pagi sampai sore, jadi mau tak mau harus dia yang mengerjakan pekerjaan rumah dan akhir nya dia mengalami pendarahan dan anak yang dikandungnya meninggal dalam rahim."
\end{abstract}

Berdasarkan informasi dari informan ditemukan tanda-tanda bahaya kehamilan tentu seorang suami benar-benar harus memberi perhatian yang lebih kepada istri. Bahaya akan kehamilan bisa menyebabkan kematian pada seorang ibu, untuk itu dituntut adanya peran suami didalam kehamilan seorang ibu, dan memberikan perhatian secara psikologis agar tidak membahayakan bayi yang dikandungnya.

\section{Analisis Spradley tentang pengetahuan suami tentang suami siaga}

Etnosains adalah sistem pengetahuan yang khas dari suatu masyarakat, dan berbeda dengan sistem pengetahuan masyarakat yang lain. Dalam studi etnosains, strategi adaptasi terhadap lingkungan bagi suatu masyarakat dipengaruhi oleh kebudayaan. Kebudayaan merupakan sistem ide dan pengetahuan yang dimiliki suatu masyarakat mempengaruhi pola tindakan mereka. Studi ini melihat bagaimana pengetahuan suami dalam menjaga kehamilan pada sang istri yang ada didalam suatu masyarakat dan studi etnosains ini bisa mendeskripsikan untuk memahami dari sudut pandang suami (emic) dan mereka bisa memahami sudut pandangnya tersebut. kebanyakan dari suami belum bisa memahami apa yang akan dilakukan ketika istrinya mau melahirkan. Untuk pengertian Suami Siaga, seorang suami dengan istri yang sedang hamil, menemani istrinya serta bisa memberikan motivasi dan memberikan dukungan untuk sepenuhnya, dan suami siap siaga untuk melakukan hal-hal bila terjadi tanda-tanda komplikasi pada kehamilan istrinya. pengetahuan harus sejalan dengan perilaku yang berlaku pada norma masyarakat dan tatanan masyarakat untuk itu pengetahuan terhadap Suami Siaga. Di dalam pengetahuan suami mengenai Suami Siaga diperlukan pengetahuan tentang bagaimana para suami bisa menjaga istrinya yang sedang hamil, dan bisa untuk menjaga istrinya dari bahaya, hal yang harus dilakukan suami untuk menjaga kehamilan istrinya adalah yang pertama suami mencari informasi yang berkaitan dengan membahayakan kehamilan istrinya. 
Di dalam pengetahuan suami mengenai suami siaga diperlukan pengetahuan tentang bagaimana para suami bisa menjaga istrinya yang sedang hamil, dan bisa untuk menjaga istrinya dari bahaya, hal yang harus dilakukan suami untuk menjaga kehamilan istrinya adalah yang pertama suami mencari informasi yang berkaitan dengan membahayakan kehamilan istrinya. Para suami juga dituntut untuk mencari upaya penyelamatan ibu hamil yang meliputi adanya pemberian pertolongan pertama di sini suami sudah bisa memahami apa yang akan mereka lakukan untuk pertolongan pertama. Ini bisa di analisis dengan teori etnosains yang mana teori ini bisa melihat pola perilaku yang ada didalam masyarakat.

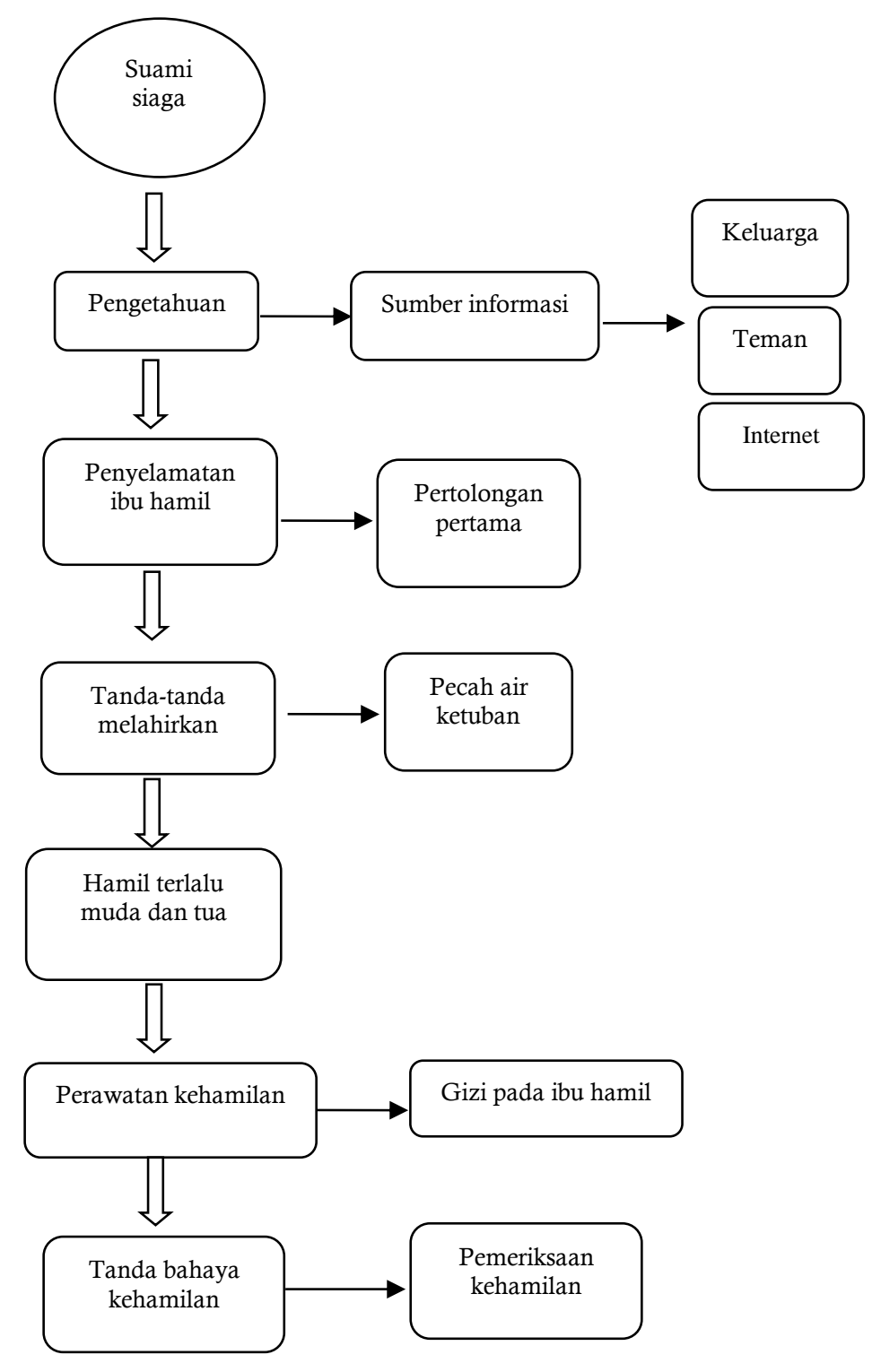

Gambar 1. Diagram Tema-Tema Budaya Tentang Pengetahuan Suami Siaga

Suami memiliki pengetahuan tanda-tanda akan mau melahirkan dengan pecahnya air ketuban, air ketuban akan keluar hendak mau melahirkan, disini para suami tidak perlu cemas, karena para suami sudah mengetahui tanda-tanda dari melahirkan. Selanjutnya perhatian suami juga tidak boleh lengah apakah usia istri sudah melampaui umur di atas 35 keatas, karena hamil di usia ini tentu akan mempunyai resiko yang lebih tinggi dibandingkan hamil di usia 20 tahun ke 
atas. Selanjutnya untuk perawatan kehamilan suami tidak boleh lengah terhadap perawatan pada istri saat hamil, gizi untuk ibu hamil harus terpenuhi, dan pemeriksaan kehamilan harus rutin dilakukan setiap bulan untuk melihat perkembangan janin. Dalam studi etnosains bisa melihat secara garis besar dan melihat secara konteks budaya dalam masyarakat pengetahuan suami terhadap istri pada saat kehamilan. Pengetahuan mengenai tanda-tanda bahaya kehamilan perlu dimiliki para suami, jika suami lengah dan tidak peduli terhadap kehamilan sang istri, maka akan berdampak terhadap kesehatan istri.

\section{Kesimpulan}

Berdasarkan hasil penelitian pada masyarakat Nagari Pakan Rabaa Kecamatan Koto Parik Gadang Diateh Kabupaten Solok Selatan, diperoleh kesimpulan bahwa informasi mengenai Suami Siaga diperoleh oleh para suami dari keluaga, teman, internet; Pengetahuan sumai mengenai suami siaga terdiri atas: 1). Suami memiliki pengetahuan dalam penyelamatan ibu hamil terutama pertolongan pertama; 2). Suami memiliki pengetahuan tentang tanda-tanda akan melahirkan ditandai oleh pecah air ketuban; 3). Pengetahuan suami mengenai bahaya melahirkan tertalu tua dan terlalu muda; 4). Pengetahuan suami dalam perawatan kehamilan yang meliputi gizi pada ibu hamil dan pemeriksaan kehamilan; 5). Pengetahuan suami tentang tanda-tanda bahaya dari kehamilan. Di antara beberapa pengetahuan suami pada kehamilan istrinya di Nagari Pakan Rabaa Kecamatan Koto Parik Gadang Diateh Kabupaten Solok Selatan, pengetahuan suami masih kurang dan belum terlaksana dengan baik. Diharapkan Pemerintah bisa memberikan pelayanan tentang Suami Siaga terhadap para suami yang memiliki istri sedang hamil atau yang baru menikah agar pengetahuan tentang Suami Siaga ini bisa lebih lengkap.

\section{Daftar Pustaka}

Asrifah, A. (2018). Hubungan Pengetahuan Dan Usia Ibu Hamil Dengan Kehamilan Risiko Tinggi Di Puskesmas Benua Kabupaten Konawe Selatan. Poltekkes Kemenkes Kendari.

Moleong, L. (2014). Metode Penelitian kualitatif. Bandung: Remadja Karya.

Depkes, RI. 2007. Keputusan Mentri RI No:900/MENKES/VII/2007. Konsep Asuhan Kebidanan. Jakarta.

Karlina, L. (2018). Gambaran Pengetahuan Suami Tentang Suami Siaga Dalam Masa Kehamilan Di Puskesmas Matakali Kecamatan Matakali Kabupaten Polewali Mandar. Jurnal Kesehatan Bina Generasi Kesehatan, 8(1), 107-117

Lucianawaty, L. (2004). Keterlibatan Suami dalam Menjaga Kehamilan Istri di Puskesmas Kecamatan Kuta Alam Banda Aceh Provinsi Nangroe Aceh Darussalam. Buletin Penelitian Sistem Kesehatan, 8(2), 100-106.

Melati, R., \& Raudatussalamah, R. (2012). Hubungan Dukungan Sosial Suami Dengan Motivasi Dalam Menjaga Kesehatan Selama Kehamilan. Jurnal Psikologi, 8(2), 111-118.

Salmah, S. (2006). Asuhan Kebidanan Antenatal. Jakarta: EGC

Spradley, J. P.1997.Metode Etnografi. Yogjakarta: Grafidian Jaya.

Raudatussalamah, R. M., \& Primasnia, P. (2012). Hubungan Dukungan Sosial Suami Dengan Motivasi Dalam Menjaga Kesehatan Selama Kehamilan. Jurnal Psikologi UIN Sultan Syarif Kasim Riau, 1(1), 111-118.

Susiana, S. (2019). Strategi Penurunan Kematian Ibu dan Anak. Laporan Penelitian BPBD Provinsi Banten

Suastra, I. W. (2006). Perspektif Kultural Pendidikan Sains: Belajar Sebagai Proses Inkulturasi. Jurnal Pendidikan dan Pengajaran IKIP Negeri Singaraja, 3(1), 10.

WHO. (2014). Health for the Word Adolescent: A Second Chance in the Second Decode. Geneva, Word health Organization Departemen of Noncommunicable disease surveillance.

Haviland, W.A. (1985). Antropologi Edisi Keempat Jilid 2. Jakarta: Erlangga.

Culture \& Society: Journal of Anthropological Research Vol. 3, No. 1, Th. 2021 
Yudiharto, A. (2016). Hubungan Dukungan Keluarga Dengan Kecemasan Ibu Hamil Menghadapi Proses Persalinan Di Puskesmas Kecamatan Mauk Kabupaten Tangerang Tahun 2016. Jurnal JKFT:Universitas Muhammadiyah Tangerang, 2(1), 1-10. 